\title{
ANALISIS RISIKO USAHATANI CABAI MERAH BESAR (Capsicum annuUm L.) DI DESA SUKALAKSANA KECAMATAN BANYURESMI KABUPATEN GARUT
}

\author{
RISK ANALYSIS OF RED CHILI (Capsicum annuUm L.) FARMING IN \\ SUKALAKSANA VILLAGE, BANYURESMI DISTRICT, GARUT REGENCY
}

\author{
Raini Hurul Misqi*, Tuti Karyani \\ Program Studi Agribisnis, Fakultas Pertanian Universitas Padjadjaran \\ *Email: raini_hm@yahoo.com
}

(Diterima 17-09-2019; Disetujui 12-11-2019)

\begin{abstract}
ABSTRAK
Desa Sukalaksana merupakan salah satu daerah yang berada di Kecamatan Banyuresmi Kabupaten Garut yang dikenal sebagai penghasil cabai merah besar. Meski bernilai ekonomis tinggi cabai merah besar merupakan salah satu komoditas pertanian yang memiliki risiko usahatani, baik risiko produksi, biaya maupun pendapatan. Tujuan penelitian adalah untuk (1) mengidentifikasi sumber risiko usahatani, (2) menganalisis tingkat risiko usahatani (risiko produksi, risiko biaya, dan risiko pendapatan), dan (3) mengetahui strategi petani dalam menanggulangi risiko usahatani. Model analisis menggunakan analisis deskriptif dan analisis risiko (koefisien variasi). Hasil penelitian menunjukkan adanya peluang risiko produksi, biaya, dan pendapatan dalam melakukan usahatani cabai merah besar. Risiko produksi disebabkan oleh kondisi cuaca dan hama penyakit yang menyerang tanaman cabai merah besar. Risiko biaya disebabkan oleh tingginya biaya yang dikeluarkan petani dalam penggunaan sarana produksi akibat dari mahalnya harga pupuk kimia dan pestisida. Risiko pendapatan disebabkan oleh kualitas produksi karena hama penyakit, tingginya biaya sarana produksi, dan fluktuasi harga. Strategi yang dilakukan petani dalam menghadapi risiko produksi adalah melakukan pemeliharaan tanaman dengan baik namun masih menggunakan bahanbahan kimia. Strategi dalam menghadapi risiko biaya adalah meminjam uang kepada bandar atau keluarga. Namun sejauh ini petani belum melakukan strategi untuk menghadapi risiko pendapatan karena sebenarnya risiko pendapatan merupakan akumulasi dari risiko produksi dan risiko biaya dan harga cabai.
\end{abstract}

Kata kunci: cabai merah besar, risiko produksi, risiko biaya, risiko pendapatan, koefisien variasi

\begin{abstract}
Sukalaksana Village is one of the areas in the Banyuresmi District of Garut Regency, which is known as a red chili producer. Although it has highly economic value, red chili is one of agricultural commodities that have farming risks, both production risk, cost and income. The research objectives are (1) identify the source of farming risk, (2) analyze the level of farm risk (production risk, cost risk, and income risk), and (3) determine the farmer's strategy of overcoming a farm risk. The analysis model uses a descriptive analysis and risk analysis (a coefficient of variation). The results showed that there were opportunities for production, cost, and income risk of conducting red chili farming. Production risk is caused by weather conditions and pests that attack red chili plants. The cost risk is caused by the high costs incurred by farmers in the use of production facilities due to the high price of chemical fertilizers and pesticides. Revenue risk is caused by the quality of production due to pests and diseases, high costs of production facilities, and price fluctuations. The strategy carried out by farmers in dealing with production risks is to maintain the plants well but still use chemicals. The strategy for dealing with costing risk is to borrow money from the dealer or family. But so far the farmers have not made a strategy to deal with income risk because the current risk of income is the accumulation of production risk and chili cost and price risk.
\end{abstract}

Keywords: red chilli, production risk, cost risk, and income risk, coefficient of variation 


\section{PENDAHULUAN}

Salah satu tanaman hortikultura yang banyak dibudidayakan di Indonesia adalah cabai. Cabai adalah salah satu komoditas sayuran yang banyak mendapat perhatian karena memiliki nilai ekonomis yang cukup tinggi dan diperlukan oleh seluruh lapisan masyarakat untuk menambah cita rasa pedas pada makanan. Secara umum cabai memiliki banyak kandungan gizi dan vitamin, diantaranya kalori, protein, lemak, kabohidarat, kalsium, vitamin A, B1, dan vitamin C. Cabai juga mengandung lasparaginase dan capsaicin yang berperan sebagai zat anti kanker (Swatika, dkk. 2017).

Kabupaten Garut menjadi sentra produksi cabai merah besar terbesar di Jawa Barat. Tahun 2016 luas panen cabai merah besar di Kabupaten Garut yaitu 6.001 Ha dengan jumlah produksi cabai merah besar mencapai 807.428 kwintal. Kabupaten Garut memiliki 42 Kecamatan yang masing-masing memiliki komoditas sayuran unggulannya. Kecamatan Banyuresmi menghasilkan jumlah produksi cabai merah besar tertinggi ketiga setelah Kecamatan Cisurupan dan Sucinaraja (Badan Pusat Statistik, 2017).

Tabel 1. Luas Panen, Produksi, dan Produktivitas Cabai Merah Besar Menurut Desa di Kecamatan Banyuresmi Tahun 2017

\begin{tabular}{clccc}
\hline No. & \multicolumn{1}{c}{ Desa } & Luas Panen (Ha) & Produksi (Ton) & Produktvitas (Ton/Ha) \\
\hline 1. & Sukaraja & 120 & 5.000 & 41,67 \\
2. & Sukakarya & 220 & 6.232 & 28,3 \\
3. & Pamekarsari & 82 & 5.970 & 72,80 \\
4. & Dangdeur & 123 & 3.100 & 25,2 \\
5. & Karyasari & 50 & 700 & 14 \\
6. & Sukalaksana & 163 & 2.100 & 12,8 \\
\hline
\end{tabular}

Sumber: Badan Pusat Statistik Kabupaten Garut, 2017

Tabel 1 menunjukkan produktivitas cabai merah besar di Desa Sukalaksana menempati posisi terendah dibandingkan dengan desa yang lainnya yaitu sebesar 12,8 ton/ha. Hal ini dikarenakan adanya berbagai risiko usahatani seperti risiko produksi, biaya maupun pendapatan yang dialami oleh petani. Menurut Ekaria (2018) risiko produksi berdampak pada kegagalan panen atau penurunan jumlah panen dari hasil yang diharapkan. Risiko biaya mencakup pada besarnya biaya produksi yang dikeluarkan dalam usahatani. Risiko pendapatan mencakup fluktuasi harga jual dan kenaikan harga sarana produksi.

Berdasarkan pemaparan di atas, tujuan penelitian ini adalah untuk (1) mengidentifikasi sumber risiko usahatani, (2) menganalisis tingkat risiko usahatani 
(risiko produksi, risiko biaya, dan risiko pendapatan), dan (3) mengetahui strategi petani dalam menanggulangi risiko usahatani di Desa Sukalaksana, Kecamatan Banyuresmi, Kabupaten Garut.

\section{METODE PENELITIAN}

Penelitian ini dilakukan dengan metode analisis deskriptif dan analisis kuantitatif statistik. Metode penentuan sampel yang digunakan adalah simple random sampling. Jumlah petani cabai merah besar di Desa Sukalaksana adalah 337 orang. Penentuan jumlah sampel atau petani responden menggunakan rumus yang dikemukakan oleh Slovin dengan $\alpha=15 \%$ dan didapat hasil yaitu sebanyak 40 responden. Data yang digunakan dalam penelitian ini berupa data primer dan data sekunder. Data primer diperoleh melalui pengamatan, pencatatan dan wawancara menggunakan panduan wawancara kepada petani cabai merah besar di Desa Sukalaksana. Sedangkan data sekunder diperoleh dari Badan Pusat Statistik, jurnal penelitian, dan berbagai sumber lainnya. Teknik pengumpulan data dilakukan melalui: (1) observasi, (2) wawancara, (3) panduan wawancara, dan (4) pengumpulan data.
Identifikasi sumber risiko usahatani cabai merah besar dan strategi petani dalam menghadapi risiko usahatani cabai merah besar dianalisis menggunakan analisis deskriptif, sedangkan tingkat risiko usahatani cabai merah besar dianalisis menggunakan analisis risiko koefisien variasi. Koefisien variasi $(\mathrm{CV})$ merupakan ukuran risiko relatif yang diperoleh dengan membagi standar deviasi dengan nilai yang diharapkan. Secara sistematis risiko produksi, risiko biaya, dan risiko pendapatan dapat ditulis sebagai berikut:
a. Risiko Produksi $: \mathrm{CV}=\frac{\sigma}{\mathrm{Q}}$
b. Risiko Biaya $\quad: \mathrm{CV}=\frac{\sigma}{C}$
c. Risiko Pendapatan : $\mathrm{CV}=\frac{\sigma}{\mathrm{Y}}$

Keterangan:

$\mathrm{CV}=$ Koefisien Variasi

$\mathrm{V}=$ Standar Deviasi

$\mathrm{Q}$ = Rata-rata Produksi $(\mathrm{Kg})$

$\mathrm{C}$ = Rata-rata Biaya (Rp)

$\mathrm{Y}=$ Rata-rata Pendapatan (Rp)

Semakin besar nilai koefisien variasi $(\mathrm{CV})$, menunjukkan semakin besar risiko yang harus ditanggung petani cabai merah besar. Batas bawah produksi, biaya dan pendapatan (L) menunjukkan nilai terendah yang ungkin diterima oleh petani cabai merah besar. Rumus batas bawah produksi, biaya, dan pendapatan adalah: 
a. Batas Bawah Produksi

$\mathrm{L}=\mathrm{Q}-2 \mathrm{~V}$

b. Batas Bawah Biaya

$\mathrm{L}=\mathrm{C}-2 \mathrm{~V}$

c. Batas Bawah Pendapatan

$\mathrm{L}=\mathrm{Y}-2 \mathrm{~V}$

Berdasarkan rumus di atas dapat diperoleh suatu hubungan antara nilai batas bawah poduksi, biaya dan pendapatan (L) dengan nilai koefisien variasi. Apabila nilai $\mathrm{CV} \leq 0,5$ maka nilai $\mathrm{L} \geq 0$, begitu pula bila $\mathrm{CV}>0,5$ maka nilai $\mathrm{L}<0$. Hal ini menunjukkan:

a) Jika $\mathrm{CV} \leq 0,5$ maka petani terhindar dari risiko dalam melaksanakan usahatani cabai merah besar.

b) Jika CV $>0,5$ maka ada peluang risiko bagi petani dalam melaksanakan usahatani cabai merah besar.

\section{HASIL DAN PEMBAHASAN}

\section{Identifikasi Sumber Risiko Usahatani}

Sumber risiko pada usahatani cabai merah besar di Desa Sukalaksana diantara adalah sebagai berikut:

a. Keadaan Cuaca

Petani cabai merah besar di Desa Sukalaksana menanam di lahan kering sehingga penanaman dilakukan pada musim hujan yaitu pada bulan Oktober April dikarenakan petani memanfaatkan air hujan yang ditampung di bak penampungan untuk menyiram tanaman cabai merah besar. Namun pada kenyataanya musim hujan menyebabkan cabai merah besar menghadapi berbagai macam risiko salah satunya adalah terjadinya pembusukan baik diakar, batang dan daun sehingga secara perlahan tanaman cabai merah besar akan mati. Selanjutnya gulma tumbuh sangat subur pada saat musim hujan dan ini menjadikan gulma sebagai risiko pada tanaman cabai merah besar. Gulma dapat merugikan dan mengganggu pertumbuhan cabai merah besar melalui perebutan unsur hara di dalam tanah, menjadi inang bagi serangga dan penyakit. Penyebaran penyakit antraknosa juga sangat cepat pada musim hujan karena jamur dapat menyebar melalui percikan air hujan maupun alat semprot sehingga dapat mengenai bagian buah yang belum terinfeksi.

Menurut Syamsiyah (2019), risiko yang dirasakan secara umum menyangkut faktor alam/lingkungan yaitu cuaca yang tidak menentu, ketidakpastian cuaca bukan hanya dirasakan oleh petani saja. Namun memang petani merupakan pelaku yang paling dirugikan terhadap factor alam/lingkungan. Ketidakpastian cuaca akan mempengaruhi kualitas dan kuantitas produk yang dihasilkan petani. 
b. Hama dan Penyakit

Hama dan penyakit yang paling sering menyerang tanaman cabai merah besar di Desa Sukalaksana adalah ulat gerayak, thrips, dan busuk buah antraknosa. Hama ulat gerayak (Spodoptera lirura) memakan daun dan buah. Gejala serangan larva berupa bercak-bercak putih yang menerawang karena epidermis daun bagian atas ditinggalkan yang mengakibatkan daun tidak berfungsi sebagai tempat fotosintesis akibatnya pertumbuhan tanaman cabai merah besar menjadi terhambat dan terganggu. Hama thrips (Thrips parvispinus) merupakan hama berwarna kuning kecoklatan, telur berbentuk oval diletakkan dalam jaringan daun. Hama thrips juga menyebabkan daun, tunas atau pucuk menggulung ke dalam lalu muncul benjolan sehingga pertumbuhan tanaman terhambat dan mati. Penyakit antraknosa atau penyakit yang menyebabkan busuk buah ditandai dengan munculnya bercak melingkar, cekung berwarna coklat pada pusatnya serta berwarna coklat muda pada sekeliling lingkarannya, bercak tersebut semakin lama akan meluas kemudian menyebabkan buah membusuk, kering, dan jatuh. Penyakit ini menyerang bagian buah cabai, baik buah yang masih muda maupun yang sudah masak. c. Sarana Produksi

Harga sarana produksi yang mahal karena meningkat setiap tahunnya membuat petani mengeluarkan biaya yang besar untuk membeli pestisida, sehingga pendapatan yang diterima petani menjadi berkurang. Hal ini selaras dengan penelitian Suharyanto (2015) yang menyatakan bahwa semakin meningkatnya penggunaan pestisida tanpa memerdulikan ambang batas tentunya berdampak negatif, karena selain akan meningkatkan biaya produksi juga akan mengancam keberadaan musuh alami bahkan meningkatkan resistensi hama dan penyakit.

d. Fluktuasi Harga

Harga cabai merah besar di Desa Sukalaksana berfluktuatif. pada saat harga cabai merah besar turun, banyak petani yang tidak panen cabai merah besar dan membiarkan cabai merah besar membusuk di pohon dengan sendirinya. Hal ini dilakukan karena apabila petani memanen cabai merah besar maka petani harus mengeluarkan biaya untuk tenaga kerja, sedangkan saat cabai merah besar dijual dengan harga murah maka jumlah penerimaan yang didapat petani hasilnya lebih sedikit daripada jumlah biaya yang dikeluarkan oleh petani untuk tenaga kerja. 


\section{Analisis Risiko Usahatani Cabai Merah Besar (Capsicum annuum L.) di Desa Sukalaksana Kecamatan Banyuresmi Kabupaten Garut Raini Hurul Misqi, Tuti Karyani}

Menurut Karyani et al (2015), fluktuasi harga cabai merah menyebabkan ketidakpuasan konsumen, sehingga mereka bergeser konsumsi mereka ke produk pengganti yang diimpor. Untuk produsen, fluktuasi mengakibatkan risiko perdagangan yang tinggi. Dalam jangka panjang, kondisi ini dapat mengurangi kepentingan dari petani dan investor untuk mengolah cabai merah, sehingga ketersediaan cabai merah lokal akan digantikan oleh produk impor.

\section{Tingkat Risiko Usahatani}

Risiko usahatani cabai merah besar di Desa Sukalaksana Kecamatan Banyuresmi Kabupaten Garut terdiri dari risiko produksi, risiko harga, dan risiko pendapatan.

a. Risiko Produksi

Hasil perhitungan risiko produksi dianalisis menggunakan koefisien variasi (CV) dengan menggunakan data produksi cabai merah besar seperti Tabel 2 .

Tabel 2. Risiko Produksi Cabai Merah Besar

\begin{tabular}{lc}
\hline \multicolumn{1}{c}{ Uraian } & Risiko Produksi \\
\hline Rata-rata Produksi & 4225 \\
Simpangan Baku (Standart Deviation) & 2917,56 \\
Koefisien Variasi (Coefficient Variation) & 0,69 \\
Batas Bawah Produksi (L) & $-1610,13$ \\
\hline
\end{tabular}

Berdasarkan Tabel 2 terlihat bahwa risiko produksi cabai merah besar di Desa Sukalaksana memiliki koefisien variasi (CV) lebih dari 0,5 yaitu 0,69 sedangkan batas bawah produksi (L) kurang dari 0 yaitu -1610,13. Hal ini menunjukkan bahwa adanya peluang risiko produksi dalam melakukan usahatani cabai merah besar. Mayoritas risiko produksi disebabkan oleh cuaca, serangan hama dan penyakit yang menyerang tanaman cabai merah besar sehingga produksi dan kualitas cabai merah besar menjadi berkurang bahkan petani terancam gagal panen karena tanaman mati. Hama yang paling sering menyerang tanaman cabai merah besar adalah ulat gerayak. Ulat gerayak menyerang bersama-sama dalam jumlah besar pada malam hari dengan cara memakan daun tanaman hingga gundul dan tersisa hanya tulang-tulang daun atau daun berlubang-lubang yang mengakibatkan pertumbuhan tanaman cabai menjadi terhambat. Selain hama, penyakit yang paling sering menyerang tanaman cabai adalah busuk buah antraknosa (Collectrotichum gloeospoiroides) atau patek. Hal yang paling merugikan adalah pada saat musim panen buah cabai yang sudah besar dan 
siap untuk dipanen terserang penyakit antraknosa sehingga buah menjadi busuk dan mengering yang menjadikan petani gagal panen.

Hal ini sejalan dengan penelitian yang dilakukan oleh Lawalata (2017) pada komoditas bawang merah yaitu bahwa risiko produksi di Kabupaten Bantul memiliki CV yang tinggi mencapai 0,85 . CV yang tinggi diakibatkan oleh variasi dalam penggunaan input (pupuk dan pestisida). Variasi produksi usahatani bawang merah yang tinggi juga disebabkan karena adanya gagal panen akibat banjir dan menyebabkan busuk umbi. Risiko gagal panen yang tinggi membuat petani rutin menyemprotkan insektisida, atau memberikan fungisida jika dirasa intensitas hujan mulai meningkat, hal ini bertujuan untuk mencegah munculnya hama atau penyakit yang dapat merusak tanaman bawang merah.

b. Risiko Biaya

Hasil perhitungan risiko biaya dianalisis menggunakan koefisien variasi (CV) dengan menggunakan data biaya cabai merah besar seperti Tabel 3 .

Tabel 3. Risiko Biaya Cabai Merah Besar

\begin{tabular}{lc}
\hline \multicolumn{1}{c}{ Uraian } & Risiko Biaya \\
\hline Rata-rata Biaya & 12.845 .800 \\
Simpangan Baku (Standart Deviation) & 16.140 .232 \\
Koefisien Variasi (Coefficient Variation) & 1,25 \\
Batas Bawah Biaya (L) & $-19434664,01$ \\
\hline
\end{tabular}

Berdasarkan Tabel 3 terlihat bahwa risiko biaya cabai merah besar di Desa Sukalaksana memiliki koefisien variasi (CV) lebih dari 0,5 yaitu 1,25 sedangkan batas bawah produksi (L) kurang dari 0 yaitu -19434664,01. Hal ini menunjukkan bahwa adanya peluang risiko biaya dalam melakukan usahatani cabai merah besar. Penyebab adanya risiko tersebut karena banyaknya biaya yang dikeluarkan oleh petani dalam hal penggunaan input seperti benih, pupuk, nutrisi tanaman, pestisida, tenaga kerja yang cukup mahal. Benih yang digunakan oleh petani adalah benih varietas viktor. Pupuk kimia yang digunakan petani terdiri dari beberapa macam yaitu pupuk kandang atau pupuk dasar, pupuk NPK, Urea, ZA, KCl, KNO, TSP. Tidak semua petani menggunakan nutrisi untuk merangsang pertumbuhan tanaman cabai merah besar. Penggunaan pestisida untuk tanaman cabai merah besar disesuaikan dengan jenis hama dan penyakit yang menyerang, semakin banyak hama dan penyakit maka petani semakin sering membeli pestisida kimia tersebut. Risiko biaya juga dikarenakan harga pupuk kimia dan pestisida yang 


\section{Analisis Risiko Usahatani Cabai Merah Besar (Capsicum annuum L.) \\ di Desa Sukalaksana Kecamatan Banyuresmi Kabupaten Garut \\ Raini Hurul Misqi, Tuti Karyani}

terus mengalami peningkatan, sehingga petani yang kekurangan modal akan mengurangi penggunaan inputnya.

Hal tersebut didukung oleh penelitian Kurniati (2014) yang menyatakan bahwa besarnya penggunaan sarana produksi tentunya akan berkaitan dengan besarnya pengorbanan dalam memperoleh sarana produksi tersebut. Semakin besar penggunaan sarana produksi maka semakin tinggi korbanan biaya yang harus dikeluarkan oleh petani. Biaya produksi yang diperhitungkan adalah biaya yang berasal dari penjumlahan biaya tetap dan biaya variabel.

c. Risiko Pendapatan

Hasil perhitungan risiko pendapatan dianalisis menggunakan koefisien variasi (CV) dengan menggunakan data pendapatan cabai merah besar seperti Tabel 4.

Tabel 4. Risiko Pendapatan Cabai Merah Besar

\begin{tabular}{lc}
\hline \multicolumn{1}{c}{ Uraian } & Risiko Pendapatan \\
\hline Rata-rata Pendapatan & 9.060 .450 \\
Simpangan Baku (Standart Deviation) & $19.089 .535,6$ \\
Koefisien Variasi (Coefficient Variation) & 2,11 \\
Batas Bawah Pendapatan (L) & $-29118621,2$ \\
\hline
\end{tabular}

Pendapatan merupakan nilai yang diperoleh petani cabai merah besar dari penerimaan terhadap penjualan hasil produksi setelah dikurangi dengan biaya yang dikeluarkan dalam melakukan usahatani cabai merah besar. Pendapatan yang dimaksud disini adalah pendapatan bersih atau keuntungan. Berdasarkan Tabel 4 terlihat bahwa risiko pendapatan cabai merah besar di Desa Sukalaksana memiliki koefisien variasi (CV) lebih dari 0,5 yaitu 2,11 sedangkan batas bawah produksi (L) kurang dari 0 yaitu 29118621,2. Hal ini menunjukkan bahwa adanya peluang risiko pendapatan dalam melakukan usahatani cabai merah besar. Risiko pendapatan dipengaruhi oleh produksi cabai merah besar, biaya yang dikeluarkan, dan fluktuasi harga.

Petani cabai merah besar di Desa Sukalaksana menjual hasil panen ke bandar yang berada di tingkat desa dengan begitu harga jual sudah ditetapkan berdasarkan kuantitas dan kualitas cabai merah besar yang di panen sehingga harga berfluktuatif. Apabila produksi yang dihasilkan sedikit akibat adanya serangan hama dan penyakit, sedangkan kebutuhan akan input produksi banyak, maka pendapatan yang didapat oleh petani pun akan berkurang. Bandar berlaku sebagai price maker atau yang menetapkan harga dan petani cabai merah besar sebagai price taker atau hanya bisa menerima harga 
yang telah ditetapkan oleh bandar tanpa memiliki posisi tawar menawar. Kerugian akan diderita petani apabila bandar yang ada tidak mampu menampung seluruh produksi yang dihasilkan petani dan memberikan harga yang jauh lebih rendah dari biaya usahatani yang dikeluarkan. Harga cabai merah besar tingkat petani di Desa Sukalaksana berkisar antara $\mathrm{Rp}$ 3.000 - Rp 11.000.

Alasan petani menjual cabai merah besar ke bandar yang pertama karena petani tidak mau menanggung biaya pengangkutan apabila dijual langsung ke pasar. Petani merasa dipermudah dengan adanya bandar yang mendatangi mereka dengan sekaligus membawa kendaraan pengangkut sehingga petani tidak perlu menyewa kendaraan lagi. Kedua, petani ingin sesegera mungkin menjual cabai merah besar dan mendapat uang setelah panen daripada hasil panen layu dan tidak laku untuk dijual. Ketiga, adanya keterikatan antara petani cabai merah besar dan bandar yang sulit dipisahkan karena didasari rasa saling membutuhkan satu sama lain.

Petani membutuhkan bandar sebagai pemberi modal dan penjual hasil panen cabai merah besar, begitupun bandar membutuhkan petani untuk bisa mendapatkan keuntungan dari pinjaman modal dan penjualan hasil panen cabai merah besar. Hubungan petani cabai merah besar dan bandar di Desa Sukalaksana bukan hanya sebagai mitra bisnis, sehingga petani terus menerus menjual cabai merah besar ke bandar karena merasa telah berhutang budi kepada bandar yang sudah meminjamkan modal. Hubungan antara petani dan bandar tersebut disebut patron-klien. Pada saat panen maka hasil pendapatan yang diterima petani telah dipotong oleh sebagian hutang petani cabai merah besar tersebut kepada bandar. Keempat, minimnya informasi petani mengenai akses pasar karena latar pendidikan petani yang rendah sehingga petani sudah terbiasa secara turun temurun menjual ke bandar. Menurut Djuwendah (2008), akses pasar bagi petani relatif sangat terbatas sehingga permainan harga di tingkat pedagang pengumpul sering terjadi. Berbeda dengan penelitian Karyani et al (2015), petani cabai merah di beberapa lokasi di Jawa Barat sudah melakukan pemasaran secara terstruktur ke industri sehingga bisa mendapatkan jaminan pasar baik harga dan jumlah cabai yang dijual.

Selanjutnya mengenai tingkat risiko pendapatan usahatani cabai yang terjadi di Desa Sukalaksana dilihat dari nilai $\mathrm{CV}$ 
sebesar 2,11. Dengan demikian risiko pendapatan adalah risiko tertinggi karena risiko pendapatan dipengaruhi oleh risiko produksi dan risiko biaya. Hal ini sejalan dengan penelitian Lawalata (2017) pada komoditas bawang merah yang menyatakan bahwa risiko pendapatan memiliki nilai $\mathrm{CV}$ yang lebih tinggi yaitu sebesar 1,24. Petani perlu berhati-hati dalam menjalankan usahatani agar risiko pendapatan dapat ditekan sehingga usahatani dapat menghasilkan produksi yang tinggi dan pendapatan yang tinggi pula.

\section{Strategi Petani Menghadapi Risiko}

Kondisi alam yang berubah-ubah memang menjadi risiko produksi yang tidak dapat diprediksi tetapi dapat dikelola dengan melakukan penyesuaian pola tanam. Pada saat musim hujan untuk mengurangi kelembapan yang tinggi, petani mengatasinya dengan cara membuat bedengan yang cukup tinggi dan lebih lebar, sehingga jarak tanam bisa diperlebar untuk mengurangi kelembapan. Untuk mengatasi serangan hama dan penyakit, petani lebih konsentrasi pada pola penanaman tanaman cabai yang baik. Hal-hal yang perlu diperhatikan guna menghindari atau menanggulangi risiko hama dan penyakit dalam budidaya tanaman cabai yaitu, memperhatikan kondisi tanah dengan cara membersihkan lahan dan tanaman yang terserang agar tidak menyebar, seleksi benih atau menggunakan benih cabai yang tahan terhadap penyakit dan melakukan penyemaian dengan baik, perawatan tanaman seperti pembersihan gulma, penggunaan bahan-bahan kimia dengan dosis yang ditentukan dan perlakuan yang rutin dalam pemeliharaan.

Strategi petani cabai merah besar di Desa Sukalaksana dalam mengatasi risiko biaya yaitu dengan cara memimjam uang kepada bandar yang nantinya pinjaman tersebut akan dibayar dengan memotong penerimaan dari hasil panen yang dijual kepada bandar. Selain meminjam kepada bandar, petani juga terkadang meminjam uang kepada keluarga. Namun sejauh ini petani cabai merah besar di Desa Sukalaksana belum melakukan strategi dalam mengatasi risiko pendapatan, karena petani cabai selama ini bergantung pada Bandar.

\section{KESIMPULAN DAN SARAN}

Sumber risiko pada usahatani cabai merah besar di Desa Sukalaksana diantara adalah kondisi cuaca, hama ulat gerayak, hama thrips, penyakit busuk buah antraknosa (patek), sarana produksi 
pertanian, dan fluktuasi harga. Adanya peluang risiko produksi, biaya, dan pendapatan dalam melakukan usahatani cabai merah besar. Risiko pendapatan merupakan risiko tertinggi karena merupakan akumulasi dari kedua risiko sebelumnya yaitu risiko produksi dan risiko biaya. Strategi yang dilakukan petani dalam menghadapi risiko produksi adalah melakukan pemeliharaan tanaman dengan baik namun masih menggunakan bahan-bahan kimia. Strategi dalam menghadapi risiko biaya adalah meminjam uang kepada bandar atau keluarga. Namun sejauh ini petani belum melakukan strategi untuk menghadapi risiko pendapatan karena sebenarnya risiko pendapatan merupakan akumulasi dari risiko produksi dan risiko biaya dan harga cabai.

Oleh karena itu untuk menekan risiko produksi disarankan sebaiknya petani menggunakan benih bersertifikat unggul cabai merah besar yang tahan serangan hama ulat dan penyakit busuk buah antraknosa yang sering menyerang tanamah cabai merah besar, serta pengendalian hama dan penyakit secara terpadu. Membentuk kelompok tani cabai besar yang terorganisir sehingga dapat dilakukan penyuluhan dan pembinaan secara rutin. Kelompok tani juga berfungsi sebagai perantara dalam memasarkan hasil secara bersama-sama sehingga memiliki bargaining position yang lebih baik dalam menghadapi pasar.

\section{DAFTAR PUSTAKA}

Badan Pusat Statistik. 2017. Statistik Indonesia. Jakarta. Badan Pusat Statistik.

Badan Pusat Statistik Kabupaten Garut. 2018. Kecamatan Banyuresmi Dalam Angka 2017. Kabupaten Garut.

Djuwendah, Endah dan Erna Rachmawati. 2008. Analisis Pemasaran dan Strategi Pengembangan Usaha Nilam (Pogostemon cablin benth) di Kabupaten Garut. Sosiohumaniora Vol 10 No. 3.

Ekaria. 2018. Analisis Risiko Usahatani Ubi Kayu di Desa Gorua Kecamatan Tobelo Utara. Ternate. Jurnal Agribisnis Perikanan, 11(2): 9-14.

Karyani, Tuti, Eddy Renaldi, Agriani Hermita Sadeli, and Hesty Nurul Utami. 2015. Design of Supply Chain Financing Model of Red Chili Commodity With Structured Market Orientation. IJABER, Vol. 13 No. 7.

Kurniati, Dewi. 2014. Analisis Risiko Usahatani Kedelai di Kecamatan Jawai Selatan Kabupaten Sambas. Jurnal Manajemen Motivasi, 10(2): 317-324.

Lawalata, Marfin, Dwidjono Hadi Darwanto, dan Slamet Hartono. 2017. Risiko Usahatani Bawang Merah di Kabupaten Bantul. Agrica Jurnal Agribisnis Sumatera Utara 10(2): 56-73.

Suharyanto, Jemmy Rinaldy, dan Nyoman Ngurah Arya. 2015. Analisis Risiko Produksi Usahatani Padi Sawah di Provinsi Bali. Agraris, 1(2): 70-77. 
Swatika, Sri, Dian Pratama, Taufik Hidayat, dan Kuntoro Boga Andri. 2017. Buku Petunjuk Teknis Teknologi Budidaya Cabai Merah Besar. Pekanbaru: Badan Penerbit Universitas Riau UR PRESS.

Syamsiyah, Nur, Lies Sulistyowati, Kuswarini Kusno, dan Sulistyodewi
Nur Wiyono. 2019. Identifikasi Risiko Usahatani Mangga Dalam Pengembangan Agrowisata di Kabupaten Cirebon. Cirebon. Sosiohumaniora - Jurnal Ilmu-ilmu Sosial dan Humaniora, 21(1): 1116. 